Trinity University

Digital Commons @ Trinity

Philosophy Faculty Research

Philosophy Department

2012

\title{
The Recovery of Archaic Truth in Literature: Light and Darkness in the Perception of Space in the Human Imagination
}

Lawrence Kimmel

Trinity University, Ikimmel@trinity.edu

Follow this and additional works at: https://digitalcommons.trinity.edu/phil_faculty

Part of the Philosophy Commons

\section{Repository Citation}

Kimmel, L. (2012). The recovery of archaic truth in literature: Light and darkness in the perception of space in the human imagination. In A.-T. Tymieniecka (ed.), Analecta Husserliana: The yearbook of phenomenological research, CXII: Art, literature, and passions of the skies (pp. 63-76). Dordrecht, Netherlands: Springer.

This Post-Print is brought to you for free and open access by the Philosophy Department at Digital Commons @ Trinity. It has been accepted for inclusion in Philosophy Faculty Research by an authorized administrator of Digital Commons@ Trinity. For more information, please contact jcostanz@trinity.edu. 


\title{
LAWRENCE KIMMEL
}

The recovery of archaic truth in literature:

Light and Darkness in the perception of space in the human imagination

\author{
On the nature of myth...
}

Myth, in the ancient Greek and extant literature we have, speaks of First Things, of the emergence of Earth and Sky and Gods, the struggles of primitive forces toward some kind of cosmic order, and the gradual political prevailing rule of Olympian order over earth, sky, sea, and the underworld. The various stories of daimons, local gods, agrarian deities of rivers and woods, deities worshipped under many names in many places gradually formed a coherent story and became reservoir and resource for Western literature. But it may be possible to extend our thinking into the archaic reach of these emergent stories to those moments of awakening in which language provided the only resource against the terror of the world. Just as Nietzsche pushed an analysis of the inspiration and energy of Greek tragic drama back into the goat-song celebration of the Satyr, so we might wonder too at the spiritual source of the impulse and enduring energy of myth in poetic consciousness that continues to fund the literature and life of the modern mind and world.

The idea of gods and forces commanded by ritual have long faded of course, though arguably the empowerment of language is still deliberative in the science and technologies of our time. But the ancient stories are still told, still woven-into the fabric of literature, still an inspiration and source of adaptation into different levels of human understanding in psychology. Whence its force? One is inclined to think that great art and literature-that which provides deep 
and thrilling experience no longer available to us through religious ritual—depends for its effect on some subliminal force, some more archaic resonance that haunts the human soul.

What we know of the origin of myth comes out of the earliest tradition of oral poetry, and the consensus is that the narratives were 'religious' in nature. Such poetic form and narratives were initially ways in which human beings discovered a means for understanding the world and forces that surrounded and often threatened them. They were also tied to ritual in which they could either seek to offset or otherwise attain a sense of command over such forces. There is reason to believe, then, that these earliest poetic expressions brought about a sense of the empowerment of language, the idea that if one can name something, if one can further put one's fear and pain into a story, then he has some control over the ever-threatening variabilities of nature and fate. The form of myth that was once embodied in religious ritual has for the most part passed into the various forms and languages of art. But Nietzsche has reminded us that the Dionysian rituals were still just beneath the surface in the tragic drama of the Classical period. While the appeal of both inner and outer space, of world and consciousness, presents an inexhaustible source for the artist and writer, at the heart of human thought in literature are primitive memories that still remain in the archaic makeup of Man and continue to haunt as well as enchant the human mind. The power of an original work of art consists often in its ability to tap primitive experiences that have yet to be subject to or endure the distancing and social abstractions of language. Such experience seems still embedded in the earliest exposure of man to the space of the universe. As an instance consider the following memorable lines--which incidentally also a offer a codicil to our concern in this essay about abstract culture-- from the First Sonnet of Rilke's Duino Elegies: 
Who, if I cried out would hear me among the angel's hierarchies?/ and even if one pressed me suddenly against his heart, I would be consumed in that overwhelming existence./ For beauty is nothing but the beginning of terror, which we are still just able to endure/...Ah, whom can we ever turn to in our need? Not angels, not humans, and already the knowing animals are aware/ that we are never really at home in our interpreted world...

The archaic mind is evident not only in the once-upon-a-time of fairy tales, but of existence itself--the closest we can get to the first order experience of the human creature to the wonder and terror of its birthing reality. Nietzsche famously discovered here the ecstasy of the uncanny in the literary resources of dream and intoxication.

Archaic remnants are still evident in the human condition, and the materials of myth remain close to the consciousness of human beings. Mythic narratives are most familiar to us from their roots in Homeric epics, in Hesiod's Theogony, and in the extensions of mythic themes in the Homeric Hymns and the great tragic dramas of the Classical period. Greek literature frames a world of Fates and Graces, Furies and Muses, in which the lives of human beings are memorably measured out by the spinning thread of the Moirae, are set in motion and ruled by a relentless logic of Eros and Moira, desire and destiny, forces that figure still in the consciousness of the modern mind and the lives they inhabit. In this literature and at this level of consciousness it is possible to discern the sometimes fragile often blurred margins that otherwise categorically divide the mythic from the historical, the literal from the figurative, disjoin the possible fusion of factive and fictive realities. Here the ordinary boundaries that constrain sensibility sometimes can be imaginatively breached in an acute awareness of individual existence.

We still celebrate the resources of spirit manifest in the character and lives that people Greek literature-in the referenced courage and will to prevail of the man-slaying warriors in the Iliad, in the dramatic shift of values in the Odyssey to craft, wit and the will to survive, where the 
compelling desire to return home, in some deep way retains its grip on the life of every human being. It was of such heroic character that Homer could proclaim that 'of one race are gods and men.' The tragic figures of Greek drama of the later period are still presented in the spirit of Dionysian ecstasy and grounded in the resolute rebellion against fate that marks the mythic image of Man in the archaic energy of Prometheus.

A primitive and residual sense of virtue is still alive in mythical literature in dramatic contrast to the later rational and domesticated virtue of classical philosophy, and even more in contrast to the imploded virtues of judgment in Judaic and Christian dogma. It is worth noting that the heroic arrogance of the tragic hero who would challenge the power and authority of the gods only to be destroyed in the effort represents an archtype of human aspiration and defeat, echoed many times over in world literature. This archaic profile of human life is a reminder that however sophisticated life becomes and however good the best laid plans of mice and men, we are still creatures with feet of clay-- how like gods in conception...this quintessence of dust. The mythic paradigm for such audacious valour in the face and fate of inevitable defeat is once again Prometheus. But on the other side of the heroic divide are the deeper and arguably more primal images of ecstasy and death in the sacrificial character and occasion of the dying and resurrected god celebrated in the dark figure of Dionysos. Finally in the total range of mythic images there is the quieter courage and human endurance of Cassandra. The terrible and terrifying isolation of this tragic figure somehow remains a deep and painful expression of the human condition.

II

It often seems the only way to understand something is to put the right question, or put the question in a meaningful way so that sense accrues to understanding even if, given the 
complexities of life and world, no comprehension is possible. How to find a coherent sense for the life-world of human beings? Literature and the arts arguably remain close to this question of sense without the abstraction of theoretical constructs that distance the sciences. There is the physical world, of course, given in its way—but also the world of physics in which the prism of theory constructs and reconstitutes the world of facts. This is true of the other sciences as wellall strive for systematic completeness within the language of their theoretical frameworkseconomics, biology, psychology.....all inform perspectives on the total facticity of world and life. Philosophy is a discipline that has tried and so far failed to find a comprehensive frame for all this, to find a fit within a larger frame for all the contributing forms and forces of science and common sense - to ferret out some sense of the whole from this fragmenting of language and thought.

Quite apart—and being apart is part of the problem —is the world and discourse of literature and the arts. This creative and loose-jointed activity represents a crucial alternative to theoretical language directed to facticity. No less fragmented than the languages of the sciences but with no obligation to systematic comprehension or conceptual preclusions, the imagination in the arts is free to pursue meaning in whatever way the inventions of language allow. The telos of artistic imagination is not to bind truth to fact but to infuse sense with meaning - to investigate the whole range of experience of mind and heart and soul with no measured concern for legitimating perception or verifying conception. It requires only creative space.

The imagination that engages literature, then, has an initial focused task not of method or theory but one that must discover or otherwise create a space in which artistic conception and expression can find its depth. It is doubtful that great literature can grow from the leveled constraints of common occurrence, and if great works of literature are still possible a different 
kind of resource and space may be required. There is an old and prevailing idea that depth in literature requires darkness. This probably comes from the persuasion that tragic drama and tragic culture are core concepts in the development of western literature. Moreover, there is always a default position available to the artist in dark times, recalled in the memorable prototype of creativity represented by Milton's Satan who, condemned to darkness, proclaims that 'the mind is its own place and of itself...' can make whatever it will for good or ill. Satan is in this context of course rationalizing his rejection and exile from the light, drawing on despair to find the energy and arrogance for rebellion. Artistic expression, under this paradigm is funded by either rage or regret. This is a reasonably desperate profile of art for which we should find an alternative. Hopefully the poet as such is not stretched to the extremes that she must metabolize her own energy feeding on her own spirit to create the space for art. The folk wisdom here is rather to light a candle than either curse or proclaim the darkness. In the search for creative space both light and shadow figure in the frame. Thus, although the resource of self is always one recourse for the artist however difficult the times in which the impulse to art arises, we should be open to the search for an alternative space which invites a depth of expression essential to great art.

It then makes sense to ask what other uncommon resources are still available to the creative spirit of literature and the arts. The imperative of art, including the genres of literature, is to make something — not think something or even do something. Poiesis (to make) is the modality required by art, and the first task of the artist is to make a space in which the expression of her imagination can come into a life of its own. Art is an imitation of life and world in many ways, of course, including cycles of light and darkness, day and night, clarity and profundity, in which imagination attends to the contrasting appeals of the beautiful and the sublime. 
Heidegger, in his search for a creative impulse in the contemporary world of language and expression draws on the poetic work of Rilke and Holderling in pursuing the question "what are poets for in a destitute and darkening time?' We will take up some of Heidegger's remarks later, but here I want to contrast the reaching resources of both the German poets and Milton's Satanic counsel with the idea of an open space of light in which the spirit can also discern depth.

The openness of the sky still presents and represents for contemporary sensibility a simple and transparent form of artistic and spiritual sense. The daylight sky is the medium through which we experience the life energies of the sun. In the darkness of night we can look through space into time itself, mark the distance of our being in terms of light-years. Once upon a time the sky itself embodied a spiritual enclosure of the Earth; indeed Uranos embraced Gaia and that union brought forth out of Chaos the elements that gradually formed the world of sense and the discourse of the arts. That was of course once upon a time, and the open sky is now, if anything, but a sense of possibility of light and space. Nevertheless in the celebration of literature this space long vacated by the gods has witnessed the prodigious courage and promethean passions that brought the fire of heavens to earth, transformed nature into world, that tamed the darkness and lighted the hearths of the human soul. There is an enduring energy to the idea of space, of open mind and expanding soul that remains a resource for imagination in art.

III

With Plato, as everyone knows, came the first serious broadside against the arts, in which literature, particularly the more passionate expressions found in archaic expressions and tragic drama, was critically dismissed as thrice removed from the serious inquiry into the truth of things. Whether or not Plato knew what was to be lost in this undermining of literature is in question, since his own literary bent was a revision of the passions of tragic drama into a 
rationalized dialogical drama. More than a change of genre, however, this philosophical twist of dramatic discourse was focused critically toward a systematic reform of human community. In place of the deeper passions of tragic culture Plato developed a preclusive rational framework tethered to a dramatic and open context of debate that proved to have a studied and indelible impact on the ideal — and fully rational—state of the Republic. More than that, it set the course of writing and thinking for centuries.

Plato's construction was designed to bind the limits and legitimacy of sense through an anti-sophistic sophistication of discourse; it signaled the advent and conceptual categories of a thoroughly enlightened world. The bright prism of light focused on a rational determination of truth and sense seemed to eat up the archaic depths of darkness that had informed tragic drama. In this way the mythic moorings of literature lost their tether to the archaic wisdom of the unconscious in the ensuing tradition and discourse of rational inquiry. This deliberative dialectic helped constitute a culture empowered with the leverage of reason in direct opposition to the passional expressions of literature and levity found in the arts. Creative literature became recessed if not excised from the serious pursuit of truth. Literature thus came to be and perhaps still is regarded as a secondary language or as both Hobbes and Locke described it, an incidental form of indulgence. Arguably the divide that occurred at that early and critical point in the intellectual history of the West has for the most part endured. There remains a separated if not hermetically sealed world of the arts distinct from that of the sciences, a forced split of the cognitive and the emotive, of positive theory and literary metaphor. The age-old war of which Plato spoke between philosophy and literature, between reason and passion goes on still.

The ensuing contrast of various forms of enlightenment, from the time of Plato thus weighed heavily against tragic culture and drama, where truth was anchored at a subliminal level 
of archaic remembrance. Centuries after Plato's 'correction of reality' as Nietzsche put it, the continued dismissal of art and the restrictive redirection of legitimate inquiry into the truth of discursive argument, was renewed and revitalized. Descartes' revision of rational inquiry led into what has become a seeming obsession in philosophical literature with the demand for 'clear and distinct ideas'. This leveled constraint of sense is analogous to the exclusion of the sublime in favor of beauty in the arts. The cogito further limited the sense and meaning of language and perception toward the securing of validity and verification. In this way any broader notion of truth still funded by fictive literature gave way to a consuming interest in the power of empirical sensibilities and the semantics of scientific inquiry.

This ensuing shift seemed to seal-off the life-world investigations of fictive literature. The fictive reality within the depths of that literature was dismissed and distanced from the empirical and material world of both science and common sense. With this cultural hegemony of hard-boiled, hard-wired sensibility, the dichotomies that separate the fictive and factive, the rational and the passional, the objective and subjective, the cognitive and emotive division of human sense and sensibility has seemed permanently divided. Cartesian counsel, in the form of a principle of methodological doubt limits the way to truth and certainty to be found only through a method of subjecting everything including one's own very existence to doubt. One begins with the comprehensive idea and total commitment of belief that everything is false. She must then work her way toward one assured thing, some concrete thing, something certain - that is, clear and distinct - through a labyrinthine abstraction of distracting shadows. This solipsistic withdrawal into the self proved vacant of depth, however--it disclosed finally only a thinking thing whose escape into existence required a grasping method of clarity. Even so, the method itself proved powerful in science and continues to command at the level of cognitive awareness 
an exclusion of mood and metaphor that fuels artistic expression. How, in the light of all this, to recover and re-direct to some broader and hopefully deeper concept of Truth in the depths of mind and spirit discovered in literature?

There are in fact several familiar resources that may be helpful for a return to the Arcadian roots of literature where the human mind is anchored to existence. The first source in the literature is Sigmund Freud. Freud, from the fundamentalist sensibility of an inchoate biological scientist, began his clinical research from the perspective of the human organism, the creature that develops a frontal cortex that separates out a distinct species, but also which never outgrows its biological heritage. The human fetus must develop in the womb through the major stages of its phylogenetic birthings in which it re-learns to breathe fluid through its gill slits, develops then loses webbed feet - the familiar philosophical expression for this phenomenal occurrence is that 'ontogeny recapitulates phylogeny.' Analogously, the brain somehow retains such archaic remembrances in the depths of the unconscious, the preconscious, the oblivion of darkness that precedes our awakening to light and world.

Freud was surely right about some things, independently of his own obsession with the rationality of science. His psychoanalytic research brought out the significance of the archaic residuals of the child's sense of vulnerability and terrors of darkness and death. He was right, in turn, about the continuance of an archaic depth manifest in the spiritual recesses of the conscious mind. Freud 'discovered' these depths of archaic myth through dream analysis where the mind is still productive independently of the censorial demands of rational discourse. This is a familiar theme also in the analytic psychology of Karl Jung. But the power of primitive expression was 
re-discovered in the arts as well, for example Picasso and others who uncovered a powerful creative resource in ancient and primitive tribal expressions of art.

The second resource for recovery and investigation of the archaic depth and vitality in literature comes from Nietzsche's early work in The Birth of Tragedy, which could as easily have been entitled 'the death of myth.' Nietzsche focused on the connection of tragic drama and tragic culture within the archaic energy of myth. He discovered in the philosophical remnants of Classical Greek drama depths still available to a culture fresh in memory from the heroic literature and mythos of an ancient oral culture. Even in the time of Plato, Aristotle and the classical Culture of Periklean Athens, mythic imagination was still alive to the gathering of the gods into the open temple of the theatre. Nietzsche's insight into the funding of myth in tragic drama focused on the annual presentation of drama at the Dionysian festival which the earliest ritual expressions of the 'goat-song' still evidenced the coming to presence of the god Dionysus in time. His argument, in short, asserts the re-emergence of the primal energies of archaic myth in the great tragic literature of the time that is still part of our conception of ourselves and of our limits as human beings. In referencing the transcendent power of myth at the end of The Birth of Tragedy Nietzsche also offers a warning--which is more a critique of what he calls 'modern ideas'--for any culture that has lost its living energy:

We are now ...able to approach the once-living reality of myth only by means of intellectual constructs. Yet every culture that has lost myth has lost, by the same token, its natural, healthy creativity....Man today stripped of myth, stands famished among all his pasts and must dig frantically for roots, be it among the most remote antiquities.

In this way, Nietzsche offers a solution of sorts to the divide of reason and passion within the context of mythic literature. He insists that whoever would discover the full range of human understanding and culture must worship at the shrine of both Dionysos and Apollo, both the god 
of darkness and the shining god of light. It is this reminder of mythic resources that suggests also a resolution of the divide of logos and mythos legislated with such confidence in the biases of empirical science, and the culture of logical empiricism. No more should the discourse of empirical science and the apologists of logical positivism replace the discourse on truth that has been the cultural heritage of literature, than the mythos of literature should try to reduce the discourse of science to a version of 'story', to insist on the universality of metaphor and fictive sense that would diminish the power of the discourse of factive truth.

Nietzsche's analysis of tragic drama argues for a broadened concept of logos inclusive of mythos. Singular depths of understanding are discovered in a range open to mythos, story, where veritas holds no dominion as the presumptive test of truth and sense. The exclusive concern for verity, the preclusive demand for verification, the static assembling of verities seem already sufficiently undermined within the creative imagination and expanding boundaries of revolutionary science. The eternal verities of sense and science appear at best eternal variables. In oppositional contrast to truth as veritas, Heidegger's late work tracing the depths of archaic or what he calls poetic discourse, will recommend an alternative conception of truth as aletheia. I will take up this idea again in a moment.

A third philosophical source revitalizing archaic language can be recognized in the socalled 'crisis literature' of the $19^{\text {th }}$ century. Nietzsche was a representative but marginal in his role as philosophical critic to the wondrous fictive literature that emerged in this period. The obvious figures here are the giants of Russian literature, particularly the work of Dostoevsky whose complex and forceful expressions of desire and dementia tap the depths and dimensions of human understanding at many fundamental levels. 
A fourth modern resource grows out of the contemplative introversion and expression of Romanticism, inspired in turn by the earlier renewal of classical Greek themes in the Renaissance. This movement of thought provides a background of energy and insight into the contemporary interpretations of existential philosophy and phenomenology where there is an existential edge to the immediacies of consciousness reflected as well in much of contemporary literature. Phenomenological investigations disclose a method that opens the visceral imagination to assimilating the essence of appearance, again mirrored in the vraisemblance of literary work. The advantage of this procedure once again dramatically overrides the biases of abstract divisions which, as we have seen, otherwise categorically separate the resources of truth in reality and appearance. Both existential literature and phenomenological research reintroduce a dramatic form of disclosure in which a depth of reality appears in the life-world of human thought and understanding.

Heidegger is yet another seminal resource of the archaic that we briefly referenced above. He is also among the major figures relevant to the issue of truth and reality in literature. His work is difficult, often seemingly digressive with obscure ruminations through tortured etymologies. More importantly for our purpose, Heidegger in his early work and later commentaries on 'poetry language and thought', develops a persuasive sense of truth in his analysis of aletheia. Whether Heidegger is 'right' in his various incursions into etymology, and in this case his translation of aletheia as "Truth" - there are many commentators who take issue with this as simplification - it is clear that his source in this analysis is mythic. A/ lethe/ ia draws on the etymology and concept of lethe, the river of forgetfulness over which the dead must pass into the underworld. Heidegger conceives of aletheia as a reversal of this journey, an unforgetfulness, as if coming into the world, into the light once again. It is useful to extend this 
analogy that, if preserved, this un-forgetfulness carries residuals of the depths it inhabited in the underworld, unconscious, archaic remembrances not easily accessible to the world of ordinary thought and perception. But if un-forgotten, such remembrance can open the mind to an awareness of the essence of things as they are, as they might appear to the innocence of a child in full possession of logos. Heidegger's design with respect to poetic language is to find a way to what he calls $d$ welling, of living a fully human life in resonance with a fully human reality_an authentic being who dwells in the presence of Being, who is not distanced or separated out in some abstract culture that alienates one from the domain and horizon of things in themselves, from the ontological essence of things. What is at stake here is nothing less than the authentic existence of the human being within the horizon of possibilities disclosed in such dwelling.

Let us return for a moment to the defining moments of the Western and Modern mind in the lasting influence of Plato and Descartes, and to the preclusive abstractions of Truth that is their heritage. Whether in the modeling of an ideal realm of the eidos, or the equally abstract recursions and reductions of Cartesian epistemology — the history of philosophy has been funded by skeptical doubt, and endures the continued refinement of attempts to exercise this critical chopping block. The strain of this exercise has sometimes the comic appearance, in the idiom of biology, much like 'the antics of an exhausted stock.' But the problem with this project is neither its intensity or its wrongheadedness, but its myopic preclusivity. It is useful, criticizing the various systematic attempts to reform language in a way that would exclude the complexities of emotional life, to cite Einstein's remark that the only thing more dangerous than ignorance is arrogance. It is hard to avoid the idea that a positivistic categorical dismissal of the total resources required for human understanding is a confluence of both disabilities. 
The fundamental and continuing appeal of fictive literature, in contradistinction to both classical ancient and modern imperatives of skeptical epistemology, is that it begins not in doubt but in belief. It is important here to mark modality and tone as well as dispositional differences. Literature, although not advocacy, begins with a positive affirmation of the spiritual in human beings. Unlike the traditional currents of epistemic inquiry and current insistencies of analytic philosophy, literature does not couch its bet concerning truth; it seldom strives for the niceties of wit, and its inspirational source is neither cleverness nor a narrow conception of knowledge. Not only is there not a demand for verification in fictive literature, there is of course no question of verification. The very creation of an imaginary world requires either a willing suspension of disbelief, as Coleridge described it, or an investment of belief in the open possibilities and disclosure of meaning. Whether such meaning is manifest in serious expressions of art and the genius of great literature, or relatively incidental in the ease of lyrical expression, it has proven vital to an understanding of what it is to be a human being.

We have seen that Nietzsche is among the few philosophical writers who attempt to track, albeit with broad strokes, the cultural development of the two seminal forms of energy in the critical and creative literature of Greece. It is not difficult to side with Nietzsche's reading of both the roots of Greek tragic drama, and the consequent transformation of its dramatic theme and form into the dialectic of formal philosophy. His discussion of the creative tension of Apollonian and Dionysian elements in drama makes a convincing framework for the constructive relationship between reason and passion in the arts. Nietzsche is ambiguously if severely critical of Socrates, most especially of the Socratic turn to philosophy, in the insistence that whatever is of value must be formulated through reason and sanitized by discursive argument. But he reserves his most serious complaints, warnings, and admonitions for what he calls 'Alexandrian 
culture' and the emergence of a theoretical temper and mindset that frames the modern scientific bias of thought, language and world.

I do not intend to extend Nietzsche's critique other than to acknowledge that Alexandrian culture has indeed seemed in part and at length designed to dry up the dynamic resources of myth still alive in the Apollinian and Dioysian tensions of darkness and light, depth and surface, madness and sanity. Literature in the modern world must contend against this dominant paradigm that puts in question the total consciousness of imaginative life, as well as unconscious and subliminal resources of meaning and expression lying at the heart of poetic creation.

Myth, Meaning, and its uses in contemporary literature.

In an age of suspicion, where spiritual issues are for the most part either ignored or subsumed into some moral program or political rhetoric, it is difficult to locate generative resources for literature beyond the social surfaces of ordinary life, or above the pathology of human relationships. Perhaps it was always this way, but we can indeed think back with Nietzsche to the time in which tragic drama during the festival of Dionysos had the effect of forcing an entire mass of people out of the social context of their particular realities drawn into the dramatic action of spiritual ecstasy of the performance. The songs and the dancing of the chorus were able to magically transform an audience into a timeless realm in which social concerns, private cares and political policies were suspended. The Satyr play that concluded the dramatic presentation tapped a deep, passionate, archaic and subliminal force of life in an otherwise sophisticated and cultured audience. This experience brought to the surface of ecstasy disclosed a creature of nature outside the time and space of the polis. The dramatic sense of 
spiritual reciprocity between the poetic expression of the artist and the aesthetic apprehension of the audience was made possible by a culture still informed and held together by a tradition of living myth. It is hard to imagine such a cultural climate of solidarity in the modern world. What may still be possible however is the response of the individual on a subliminal level and on the basis of the archaic residuals of consciousness not dependent on a particular cultural tradition.

There are many traditional sources of rendering of myth after Greek literature and the Roman adaptations and refinements of Ovid; from Chaucer and Milton through Shakespeare and Goethe, the Romantic poetry of Tennyson, Keats, Shelley—including Mary Shelley's remarkable accessing of archaic myth into frightening parable of Frankenstein —on into the contemporary period of art and literature. These traditional resources remain open to the literary imagination in spite of the continued academic wringing-out of the archaic energy of myth through critical and scholarly perspectives.

I can think of several contemporary works still close to the spirit of myth, that perhaps contain the echo of the archaic. For example short brilliant pieces like Jackson's The Lottery, or Le Guin's Those who walk away from Omelas, or of course and indeed in the more complex experiments of mythic energy in the masterpiece of Joyce's Trilogy. A work of contemporary myth that comes to mind within easy reference and scope, is a seriously humorous effort with a profound theme in John Barth's Night Sea Journey.

But finally, it is a different question, and one that still remains to be answered, of finding archaic resources of mind and spirit open to the creative imagination still embodied in living cultures. One example of this with which I am intimately familiar, may be found in the tribal cultures and oral traditions of the Native Americans. Here the culture and communal life of the 
people remain close to the earth, and the ancient and retold stories that preserve the memory and identity of a people exemplify the power of language and myth. I have discussed at some length elsewhere in the volumes of Analecta Husserliana, the way in which these tribal cultures present a lesson for the abstract vacancies in the spiritual life of the dominant European cultures, and I offer here a representative story adapted as a poem, from the Lakota writer Leslie Marmon Silko. The earlier essay in which I discussed this oral literature argued a very different point about life and literature. But here, I suggest only that the reach of memory in the voice of the poet may be evident - and perhaps also, the echo of a longing of the soul for what is being lost.

In the spirit, then, of an oral tradition you might imagine I am telling you the following story, "intending it":

Long ago, out on the high desert below Turquoise Mountain, there was a meeting of witches.

And there was a contest to see who had the strongest medicine, the greater power.

One witch danced and brought forth rain from a cloudless summer sky.

Another beat an ancient sacred drum, and its rhythm slowed the current of the river and stirred the high mountain Aspen and Pine.

Another drew lines in the sand with a stick and snakes came to rest in the hollows.

"What I have is a story," one witch said, and the others laughed, at first.

"Go ahead, laugh if you want to, but as I tell the story, it will begin to happen:

Across the ocean in caves of dark hills, are white skin people,

like the belly of a fish, covered with hair.

These people grow away from the earth. Then they grow away from the sun.

Then they grow away from the plants and animals.

They see no life.

When they look, they see only objects.

The world is a dead thing for them.

The trees and rivers are not alive, the mountains and stones are not alive. 
The deer and the bear are objects. They see no life.

These are people of fear. They fear the world.

They destroy what they fear. They fear themselves.

....Set in motion now... set in motion... to destroy, to kill.

...Whirling...whirling..."

So the other witches said: "Take it back; Call that story back!"

But the witch just shook its head at the others in their animal skins, fur, and feathers.

"It's already turned loose. It's already coming. It can't be called back."

...after Leslie Marmon Silko

The citation of this poetic expression intends to underscore a cultural contrast perhaps familiar enough in literature but too often forgotten in our ordinary, social, and professional lives apart.

The second instance of a culture with a sense of archaic myth still alive to the in the myth-making intelligence of the contemporary mind may be indexed through the work of the Caribbean poet and Nobel Prize Laureate Derek Walcott. In his epic work Omeros Walcott retells the story of the conflict of Achilles and Hector from the standpoint and in the colonial idioms of another sea driven people:

"O-meros", she laughed "That's what we call him in Greek," stroking the small bust with its boxer's broken nose, and I thought of Seven Seas sitting near the reek

Of drying fishnets, listening to the shallows' noise. I said: "Homer and Verg are New England farmers, and the winged horse guards their gas-station, you're right"

I felt the foam head watching as I stroked an arm, as cold as its marble, then the shoulders in winter light in the studio attic. I said "Omeros"

And $O$ was the conch-shell's invocation, mer was 
both mother and sea in our Antillean patois,

Os a grey bone, and the white surf as it crashes

and spreads its sibilant collar on a lace shore.

The Nobel committee described Walcott's work as "a poetic oeuvre of great luminosity, sustained by a historical vision, the outcome of a multicultural commitment." But in fact, the sense and force of Omeros is profoundly mythic. The theme that binds the characters of this surprisingly broad and intimate epic together in spite of profound passions in conflict, is an equally strong and universally expressed human desire for communion with the past.

Arguably, we have much to learn from such cultures and cultural expression. But as long as there is a deep desire for communion with the past and for the moorings of our cultural and spiritual life, then even within the abstract cultures that dominate the contemporary world the dimensions of the human soul will remain an open possibility of great literature. 